\title{
Germline Mutation
}

National Cancer Institute

\section{Source}

National Cancer Institute. Germline Mutation. NCI Thesaurus. Code C17666.

Any mutation that appears in the gametes and which will therefore be transmitted to the progeny with some frequency. 